Vol. 13 , No. 1

ISSN: 2085 - 4609 (Print), e- ISSN 2656-0208

Journal homepage: bit.ly/UltimaComm

\title{
Gender and Digital Public Relations: Who Gets Benefits?
}

\section{Nobertus Ribut Santoso}

To cite this article:

Santoso, N.R. (2021). Gender and Digital Public Relations: Who Gets Benefits?, Ultimacomm, 13(1), 108-122.

https://doi.org/https://doi.org/10.31937/ultimacomm.v13i1.1998

Ultimacomm publishes research articles and conceptual paper in the field of communication, mainly digital journalism and strategic communication. It is published twice a year by the Faculty of Communication of Universitas Multimedia Nusantara

Submit your article to this journal $\square$

Published in Partnership with

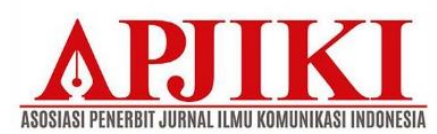

Full Terms \& Conditions of access and use can be found at http://ejournals.umn.ac.id/index.php/FIKOM/about 


\title{
Gender and Digital Public Relations: Who Benefits from the Advancement of the Technologies?
}

\section{Nobertus Ribut Santoso}

Universitas Atma Jaya Yogyakarta; College of Mass Communication, University of the Philippines Diliman

Email: nobertus.ribut@uajy.ac.id

Received Apr. 14, 2021; Revised Jun. 24, 2021; Accepted Jun. 29, 2021

\begin{abstract}
This research investigates how the advancement of digital technologies benefits for male and female public relations professionals. Through a systematic review method, this research gathers the data from relevant existing texts of public relations, genders, and digital technologies published from 1990 to 2020, with a total of 40 journals published from various publishers. After analysing, criticizing, and synthesizing, the findings show that although females dominate public relations, male public relations professionals have a privilege to dominate the top positions since they have been participated in the managerial roles while female are in the technical roles. In the organization, female public relations practitioners face inequalities in social, professional, and economic areas and they also find it difficult to achieve higher position because the traditional patriarchy is still strongly practiced. It is harder for them to break this barrier. Family and children, on the other hand, become big considerations for females to climb the higher position since it will give bigger responsibilities. Moreover, the massive development of digital technologies provides more opportunities for female public relations professionals to intensively engage with the stakeholders. On the other hand, these technologies bring privilege for males since they are more digital technical skills. This research suggested that to compete with males in digital public relations, females should enhance their digital skills, wisely manage their time, learn to take new challenges making them one step ahead, and actively participate in every organizational activity to voice their ideas and straighten up false assumptions and misconceptions about females. Meanwhile, males should be versatile public relations professionals in the digital era by combining masculine and feminine values to find the best public relations practices.
\end{abstract}

Keywords: digital public relations, gender discrepancy, feminine values, patriarchal system, professionality

\section{INTRODUCTION}

Females have traditionally dominated the profession of public relations. More than $70 \%$ of public relations practitioners are females (Janus, 2008). At the higher education level, $70 \%$ to $80 \%$ of students taking public relations courses are females (Grunig et al., 2000). Therefore, the public relations profession is heavily stereotyped as a feminine profession, despite the fact that many females pursue this occupation. The increased number of 
females deciding to be public relations practitioners encourages a debate over this occupation's feminization since World War II. This profession's female domination occurs when many women love this profession since they feel that this profession belongs to their passion. They enjoy it because this job offers them opportunities to complete tasks (Beatty, 2013). Thus, people label the public relations profession as a feminine profession because it involves honesty, justice, and sensitivity (Andsager \& Hust, 2005). These feminine values become the core of this profession, mainly when public relations activities are primarily carried out in service industries.

This article assumes the public relations profession is currently dominated by females (Beatty, 2013). As media and business industries develop, public relations professionals become increasingly important because of their ability to cultivate friendly relationships with any parties (public, stakeholders, businesses, and other organizations). Therefore, the feminization of public relations has only favored females for they have good communication skills (Beatty, 2013). They serve to harmonize the relationships with all stakeholders. For organizations needing public relations professionals to harmonize the relationships with stakeholders and make up the organization to have a good image, placing females in this occupation could be the right choice. A good image determines the organization's success in the midst of business competition (Lovis, 2020).

Although women in the workplace dominate this profession, some scholars reported that female public relations professionals are still facing institutional sexism; a system of unfair advantages that are given exclusively to men (Grunig et al., 2013, p.3). Overcoming this problem remains a significant challenge since the patriarchal system is still intensely practiced. Furthermore, females experience vast gender inequalities in social, professional, and economic areas (Beatty, 2013). The patriarchal system might contribute to these inequalities since most organization leaders are males.

Public relations could be then said as a gendered field (Daymon \& Demetrious, 2010). Gender refers to complex systems of personal and social relations through which men and women are socially created and maintained and through which they gain access to, or are located, status, power, and material; resources within the society (Barriteau, 1994). Gender also refers to the characteristics that either society or culture tends to symbolize roles of each sex as masculine or feminine, which influences personal identities (Little et al., 2016). Therefore, as a profession, public relations are a social construction product driving how public relations professionals should behave based on their attributes as public relations professionals. These attributes guide them in performing their behaviours.

Although society constructs the profession of public relations as a feminine occupation since it is dominated by females, in terms of professional, male public relations practitioners achieve higher positions in the organization (Krugler, 2017). They could reach manager and director levels. Therefore, since males dominate the higher level of 
public relations, it can be said that the higher the position of public relations, the more masculine of the public relations practices can be found. This assumption is based on the construction of power and patriarchy (Douglas, 2012), where males dominate society through their power. Through power, they can control and make decisions bringing advantages to males.

On the other hand, a massive development of digital technologies brings challenges for male and female public relations professionals to adopt these technologies in their works. These platforms have changed the way they communicate with their stakeholders. The communication tends to be dynamic, and through their fingertips, public relations professionals and their stakeholders are intensively connected. Public relations professionals could produce creative and exciting content and upload them on websites and social media accounts, while stakeholders could directly experience those contents and respond to the contents. Digital platforms have the potential to significantly increase stakeholder engagement. As a result, when it comes to public relations and digital technologies, the question of who benefits from the advancement of these technologies may arise.

\section{METHODS}

The literature review was chosen in this study since it helps the researcher in summarizing tremendous literature around a concept or phenomenon (Snyder, 2019). This study, on the other hand, followed an integrative literature review. Snyder (2019) also cited that the integrative literature review aims "to provide an overview of the knowledge base, to critically review and potentially reconceptualize, and to expand on the theoretical foundation of the specific topic as it develops". Therefore, it allowed the researcher to capture data from various related fields, but not to cover all journals that have been ever published on the topic. The researcher combined different perspective from the various articles to establish new insights.

Relevant existing texts of public relations, gender, and digital technologies were reviewed to identify how public relations and gender is discussed and who get benefits from the development of digital technologies in doing public relations activities. In identifying the related journals, the researcher employed Google Scholar. The researcher took a raged of published articles from 1990 to 2020 for the desk research study. There were 40 journals published from various publishers. After identifying the relevant texts, the researcher analyzed, critiqued, and synthesized them to get in-depth insights in meaning-making information that is relevant to this study. Then, the researcher presented the findings and discussed them in order to answer the purpose of this study. 


\section{RESULTS AND DISCUSSION}

In understanding public relations' social construction, it is essential to examine its gendered nature (Daymon \& Demetrious, 2010). Gender is formed based on social construction (Juschka, 2001). Discussing gender cannot be separated from sex. Although gender is different from sex, it has a strong relationship. People are born as males and females, but they learn to be, are conditioned to be, or feel themselves to be "feminine" or "masculine" (Rolleri, 2013). Meanwhile, sex refers to a biological reality of male and female sexual difference (Juschka, 2001), for instance, chromosomes, internal and external reproductive organs, hormones, and specific physical characteristics (Rolleri, 2013). Therefore, gender is dynamic. Masculine and feminine values in a particular community could differ from other communities depending on their perspectives and experiences on gender.

Socially and culturally, masculinities are awarded over and above femininities (Sultana, 2010). This phenomenon causes gender inequality in the organization where managerial work acts as a reinforcement of men and women into traditional gender roles. As a result, females hold a lower position in the hierarchy of the structure. Therefore, they earn lower wages than males (Zwiech, 2009). Lacking professional experience, manager role enactment, participation in decision-making, and career specialization drive women to be a second class in the organization (Dozier, Sha, and Shen in Krugler, 2017). Also, people assume that males are more productive than females (Zwiech, 2009). Consequently, this stereotype becomes a significant consideration for the organization to hire males since they will benefit the organization. Zwiech also (2009) argued that males are more productive than females. It could explain that males enjoy their privilege in social society in the hierarchical structure. They get more benefits of the virtue of their gender since it seems no barriers for them to pursue their dreams. Thus, in the organization, males get more opportunities to develop their career.

Regarding gender issues, society labels which occupation is considered more appropriate to males and females based on its attributes. The society opined that males identify to work at heavy industries, constructions, army institutions, transportations, economics, sales, and commerce. Simultaneously, females are better to work in areas of personal care services, education, secretarial or office work, nursing, caretaking, marketing, Public Relations (PR), and Human Resource (HR). These stereotypes are based on the dominated gender in the work areas that require skills and characteristics traditionally attributed to men and women (Andsager \& Hust, 2005). Therefore, people identify public relations as an occupation for females because this profession's characteristics are feminine (Beatty, 2013).

The profession of public relations, on the other hand, is a result of a social construction formed by society. This construction has impacts on power relations and privilege for 
both males and females (Daymon \& Demetrious, 2010). Wherever their position in the organization's structure, both males and females have the authority to complete their tasks. However, the authority that they have is different based on the position they can achieve. Male public relations professionals' authority in the organization is more extensive than females since males have privilege opportunities to achieve higher levels, particularly in the patriarchal organization. Most male public relations can achieve higher positions in the organization, such as managers and directors of public relations.

Gender issues in public relations refer to what males and females should do in this profession (Tsetsura, 2014). Digital public relations, precisely gender issues, relate to digital public relations activities. Based on the job descriptions, generally, there are no differences between male and female public relations practitioners. They conduct their job based on job descriptions given by the organization. However, gender issue on public relations derives the inequality coming from career roles, salary, advancement opportunities, and sexual discrimination and harassment (Grunig et al., 2013, p.4-5). In the roles of males and females in the organization, females put more in technical roles rather than in managerial roles (Toth \& Grunig, 1993). Also, female public relations professionals do not get involved in making business strategies. They focus more on activities dealing with customers. Therefore, female public relations practitioners have less opportunity to use their talents and abilities in creating successful relations with the media and various publics (Beatty, 2013). Meanwhile, male public relations practitioners perform more on managerial tasks. Thus, they get more opportunities to advance their positions (Grunig et al., 2013, p.2) since they participate in making organizational decisions to compete with others and win markets.

Gender issues in public relations also bring impacts on how people see this profession. The stereotype of public relations is presented as a profession that is enjoyable, easy, and dependent. These are attributed to femininity (Tsetsura, 2014). Consequently, these stereotypes cause prejudice toward public relations professionals. People then assume that this occupation does not constitute a real career (Beatty, 2013). However, females now dominate this profession since more females are interested in entry this profession. They argue that this profession offers them opportunities to be creative, communicative, and emotional of listening, serving to counsel, and dealing with problems and able to enhance writing skills, build networks, and do multi-tasking job (Beatty, 2013).

The domination of females in this profession should ideally bring advantages for females since the domination can hold legitimation over the population (Thompson, 2013). However, female domination of public relations cannot strengthen their bargaining in the organization. This domination precisely becomes a barrier to achieve a higher position because of the patriarchy. The more females enter this occupation, the weaker their position will be, creating a gender pay gap. Krugler (2017) pointed out that females' domination in the public relations profession (around 70\%) gives direct impact on 
income. More than a half of them earn less than males. Also, the inequality of public relations professionals drives sexual discrimination and harassment. Some female public relations professionals are being sexually harassed by males in their office. Ironically, females' appearance becomes a critical determinant in this harassment. People assumed that attractive females could not work hard, and men feel uncomfortable around attractive women since they cannot concentrate (Grunig et al., 2013, p.321).

The gender gap in public relations will be existing in line with the trends of increasing females in this occupation (Daymon \& Demetrious, 2010). This gender discrepancy has disadvantageous impacts on females in terms of the wage gap, job security, mentoring opportunities, and influence in departments (Tench, 2017). Thus, females become the victims of this trend. They do not have efforts to fight this discrepancy since they might accept their discretion as females under masculinity hegemony.

On the other hand, the dramatic development of digital technology impacts how male and female public relations communicate with their stakeholders to build good relationships with them. However, since technology is closely related to males' life, some scholars opined that males' access to digital technology is better than females. Also, males' digital skills are more advanced than females (Andok, 2019; Helsper \& Van Deursen, 2015). These facts could provide more opportunities to males to pursue public relations professionals and advance their careers since they can make enormous contributions to the organization through their digital technology skills. To compete with males, female public relations professionals should enhance their digital skills to have equal digital competencies. Therefore, empowering females to have digital capabilities is crucial in this digital era in order to be equal with males (Suwana, 2017).

Public relations can be understood as a distinctive management function that helps establish and maintain mutual communication lines, understanding, acceptance, and cooperation between an organization and its publics. Therefore, public relations professionals are crucial in the organization since it involves managing problems or issues, helping management keep informed on and responsive to public opinion. Public relations professionals emphasize management's responsibility to serve the public interest (Seitel, 1995, p. 6). To understand its public, public relations should be active and dynamic. Therefore, there are four specific public relations functions: research, action, communication, and evaluation (Seitel, 1995, p.7).

Public Relations (PR) plays pivotal roles in the organization for it has functioned as a management to develop and support the organization's business strategy. Therefore, PR can help the organization achieve its objectives effectively and efficiently and create and maintain the image and minimize and manage the organization's conflict (Grunig \& Dozier, 2003, p. 2). Also, PR is functioned to communicate the organization in order to be well-known by public through unique and interesting stories (Santoso \& Negoro, 2019). 
Those concepts of public relations can be highlighted that communication skills become essential factors required to be public relations practitioners because they must maintain good relationships with the public, maintain and enhance the reputation of the organization, and solve the problems or crises faced by the organization. Also, public relations professionals should have analytical skills to understand the stakeholders and plan communication goals, particularly in the digital age. They should not only be able to use digital media to maintain and enhance the reputation of the organization, but they must understand digital media strategies to optimize in disseminating messages to the public, manage a crisis, and clarify misinformation.

Digital public relations, on the other hand, can be understood as online activities conducted by public relations professionals. These activities aim to inform stakeholders about an organization's services and updated information regarding the services. Therefore, public relations professionals' contents should attract and increase visitors to the organization's website and its official social media account. Besides, digital public relations professionals should make strategies to optimize the use of websites and social media to engage stakeholders and enormously increase the highest ranking in search engines (Gifford, 2010). Therefore, digital public relations professionals are also functioned to virtually manage and enhance the organization's image and reputation.

On the other hand, by profession, "considered as a reasonably well-defined occupation that meets a defensible set of criteria for being a profession" (Lester, 2015), public relations occupation is more appropriate to and dominated by females since they are great communicators, having good abilities in persuading and engaging in a conversation. Females also have a strong mentality in listening to their publics. In terms of negotiation, females are much better negotiators than males because they can compromise with the public without yielding their position. Besides, this occupation requires attention to detail and a step-by-step ability to follow a plan that could be more appropriate to females (Tsetsura, 2014).

It is also interesting to note that by profession, females dominate the profession of public relations. It can be revealed that most members of the biggest public relations profession association, the Public Relations Society of America (PRSA), are females. Melgin (2012) noted that in 2011, the share of females in PRSA was 71\%. The traits of this profession can attract females to involve in this job. Therefore, this profession is feminine oriented since this profession is based on feminist values where honesty, justice, and sensitivity become the essential parts, which will enhance the symmetrical communication patterns of public relations (Grunig et al., 2000). Other feminine values such as cooperation, respect, caring, nurturance, interconnection, equity, perceptiveness, intuition, altruism, fairness, morality, and commitment also attract more females to pursue this profession (Grunig et al., 2000). 
Although by profession, nowadays public relations profession is more appropriate to females, males have opportunities to pursue this profession. Males should be versatile public relations professionals, particularly those working in service industries. Males must be able to understand when they must use their masculine values in working and when they must absorb feminine values and combine their masculine values with feminine values to find the best practices of public relations activities.

On the other hand, discussion of the profession of public relations cannot be separated from its professionality. Professionality can be defined as "an ideologically-, attitudinally-, intellectually-, and epistemologically-based stance on the part of an individual, in relation to the practice of the profession to which s/he belongs, and which influences her/his professional practice" (Evans, 2002, p.6-7). Based on this concept, both male and female public relations practitioners can show their professionality of practicing public relations activities to achieve the organization's goals. However, in terms of professionality in achieving a higher position of public relations, females get barriers. The biggest challenge is their family. They get difficulties climbing higher levels because they have to consider their time with their family (Janus, 2008). Females also feel fear when they have a higher position in the organization because it will impact their children (Krugler, 2017). Therefore, being feminine females becomes a significant consideration rather than competing with males. This way could lead them to achieve higher self-esteem where the culture requires them to follow feminine values (Starr \& Zubriggen, 2017). To be equal with males, female public relations professionals should wisely manage their time, learn to take new challenges that can make them move one step ahead, and actively participate in every organizational activity to straighten up false assumptions and misconceptions about females.

Therefore, by professionality, this occupation is also dominated by females and they function as a glass ceiling within the field. Females tend to stop on their way to the top because they get difficulties achieving the top positions (Krider \& Ross, 1997). Moreover, in the organization, they lack opportunities and get prevented from obtaining promotions and get placed into management positions. On the other hand, working as public relations practitioners encourages considerable efforts to be a barrier for females. This job requires an inevitable sacrifice. The higher up one goes, the more sacrifice one makes (Janus, 2008); since working as public relations practitioners, one has to be ready 24 hours to prevent or solve problems faced by the organization and take beneficial opportunities that can be valuable for the organization.

Since male public relations can achieve higher positions in the organization, they have the power to control the organization, and they are also able to control female employees since they have the ability to produce planned and predicted effects on others (Domhoff, 2012). With the power that male public relations practitioners have, especially when they are in management positions, they can influence others to follow the strategic plans they 
have made by considering three leading indicators such as 1) who benefits? 2) who governs? and 3) who wins? (Domhoff, 2012). Therefore, male public relations practitioners having the most power get benefits because power in the organization represents the structure or position. The more powerful they have and the higher position they achieve, the more money they get. Also, their advanced digital skills can enhance their power. With power, they manage the organization to achieve the goals. If they are successful, they win. This situation will strengthen their bargaining positions in the organization.

Gender differences derive from males and females' issues and masculinity and femininity, where males are constructed to be masculine and females to be feminine. Gender issues also go into the public relations profession. In the early development of public relations, this profession is masculine, where males dominate this occupation. In 1973, Umeogo and Ifeoma (2012) noted that there are more male than female public relations practitioners.

Furthermore, masculinity has enormous impacts on public relations in male domination. It can be seen from at least two males who have given significant contributions to this occupation's development. Edward Bernays (1891), the pioneer leading dialogue of public relations, is well-known as a public relations counsel. Another public relation figure contributing to the development of this profession is Ivy Lee. If Bernay contributes to the public relations field and practice, Lee (1877), an ex-reporter, is the first practitioner of a modern-style public relations practice. In conducting public relations activities, those two males focus on publicity and media relations (Newsom et al. in Beatty, 2013). Therefore, in the early development of public relations, this profession functioned to inform any information from organization to public since the communication flow is one-way where the public is passive.

The masculinity of public relations can also be seen from the practice of public relations in World War I. It is practiced in the form of propaganda in order to demonstrate effective persuasion, dealing with other countries (Newsom et al. in Beatty, 2013). Therefore, masculinity takes a pivotal role in developing public relations practice in this period since war is identified as a male area.

The domination of public relations practitioners changed in around 1950-1960 since females are able to enter this job. The number of females entering this occupation massively increased. In 1950, there were only 1,958 female public relations professionals, while in 1980, there were 68,595 (Reskin \& Roos, 1990, p.134). Many colleges and universities opening public relations classes become a fundamental reason why females dominate the profession of public relations. Lamme (2007) noted that in 1956, ninety-two colleges and universities were offering public relations classes and most students were females. Therefore, the practice of public relations is more feminine because of the 
feminine values embedded in this profession--public relations deals with interaction with the publics.

Since communication technology connecting to the world was founded in 1980, public relations have become a popular profession for the development of business and organizations (Beatty, 2013). Although the number of male public relations practitioners is fewer than females, male public relations practitioners are able to move into CEO slots while females cannot achieve this position. Most female public relations practitioners hold lower positions and earn less than males even though they are in the same position (Newsom et al. in Beatty, 2013). The ability in mastering digital technology contributes to males to achieve higher levels in the organization since digital media has changed the way organization communicates with its stakeholders.

Originally, masculinity influences the improvement of public relations. However, femininity gives contributions to the practice of this profession. Questioning on if males or females are more appropriate to this occupation has already answered. Both males and females can do this occupation since the public relations profession is fluid and digital public relations. On the other hand, questioning what males should do when entering this profession where females dominate it becomes an interesting question. In order to be able to conduct this occupation, males should adjust their behavior to fit in with females and demolish adverse feminization trend effects (Pompper \& Jung, 2013). Thus, males should follow the feminine values of public relations. However, they could also combine feminine values with their masculine values to find other best public relations practices, complaint handling. When male public relations professionals face complaints from their stakeholders, either the complaints are expressed through face-to-face or mediated communication, feminine values play essential roles in understanding the problems to empathize with the stakeholders. In making decisions or solutions to the stakeholders' problems, male public relations professionals could confidently use their masculine values. The decisions or solutions should be firm and logical.

Historically any profession is mainly dominated by males. The construction of power and patriarchy influences the professional domain. Males have the power to determine legitimation and create organizations and systems reflecting dominant interests (Douglas, 2012). Therefore, males dominate the higher levels of the organization, including public relations.

On the other hand, it is harder for female public relations practitioners to break the boundaries of patriarchy in order to be equal with males since males have dominated public and private spheres. Patriarchy gives absolute priority to males and limits females' human rights. Therefore, females' position is always lower than males (Sultana, 2010), and females are oppressed by men (Ademiluka, 2018). To gain the power, female public relations must have excellent capabilities in the profession of digital public relations. They 
must also master the use of digital technologies, work harder to get promoted, and wisely manage their time both for the organization and family.

Furthermore, females are subordinate, and the subordination of females forces them to stay under the control of males. In keeping females and males' control, patriarchy operated and hegemonized some social customs, traditions, and social roles (Sultana, 2010). Patriarchy in digital public relations works through actions and behaviors expected of organizational culture. Since hierarchically males have higher positions, they have the authority to set the organizational culture that can control the employees' activities and behaviors to achieve the organization's goals digitally.

Traditional patriarchy brings males to the top position in society. Position automatically goes to the power. Although the number of male public relations practitioners is fewer than females, males have more power since they achieve a higher structure (Umeogu \& Ifeoma, 2012). In other words, the status of one determines his power. Status can be defined as either professional through the kind of job one does or hierarchically through the position one occupies in the organization (Robin in Umeogu and Ifeoma (2012). Since females' status in the patriarchy is lower than males, it impacts their power. They might only do technical activities of digital public relations. They could not have opportunities to do strategic digital public relations activities since males dominate higher levels in the organization.

Male public relations practitioners with higher status will contribute to the organization to achieve the organization's business goals. Thus, as males, they might maintain practicing their patriarchy. Although there are more female public relations practitioners, patriarchy keeps going strong. Besides, females find it hard to be equal to male to get better positions since the media portrays female public relations practitioners as "corporate prostitutes" to attract customers (Umeogu \& Ifeoma, 2012). However, males might adopt feminine values and combine them with masculine values to find public relations best practice.

Regarding the digital public relations activities, females use digital media, particularly social media, more than males (Kimbrough et al., 2013; Perrin, 2015); this situation could bring opportunities for female public relations to engage with the stakeholders intensively. They can give updated information to the stakeholders and personally communicate with them to deeply understand their stakeholders before making communication programs. On the other hand, since males have higher digital technical skills than females (Dodel \& Mesch, 2018), the profession of public relations could provide more opportunities for males to pursue it. Through their digital technical skills, males can advance the organization's websites and other social media official accounts to a higher rank in Google search engine. 
It is also interesting to note that male public relations professional should be versatile in the digital era. They must be able to adjust to any changing environment. Having masculine values in the domination of feminine values should be the most advantageous for males to enrich their digital public relations activities. On the other hand, females should enhance their digital competencies to be quale with males' digital skills. Therefore, leaders of the organization might give equal opportunities for male and female public relations professionals to achieve the highest levels of their career in digital public relations.

\section{CONCLUSION}

Females have traditionally dominated the public relations profession. They are hired because they have strong communication skills and the ability to persuade, converse with, and listen to stakeholders in order to build and harmonize relationships with them. Male public relations practitioners, on the other hand, dominate at the top because they have held managerial positions, whereas females have held technical positions. Female public relations practitioners face some inequalities in social, professional, and economic areas. They also struggle to advance in the organization because traditional patriarchy is still prevalent. Furthermore, as digital technologies advance, female public relations professionals will have more opportunities to engage in intensive stakeholder engagement. Males, on the other hand, have an advantage because they have more digital technical skills. Females must improve their digital skills, learn to manage their time wisely, learn to take on new challenges, and actively participate in all organizational activities to voice their ideas and correct false assumptions and misconceptions about females in order to compete with males in digital public relations. Meanwhile, in the digital age, men should be versatile public relations professionals who combine masculine and feminine values in order to find the best public relations practices.

Although this article does not provide empirical data, it has offered a starting point in providing a solid foundation of male and female public relations professionals in the development of digital technologies. The scholars could further investigate this topic by providing empirical data in order to deeply understand how male and female public relations professionals adjust the advancement of digital technologies supporting their public relations activities. For human resource officers, this study could be a consideration whether they will hire male or female public relations professionals in order to achieve the success of the organization. 


\section{REFERENCE}

Ademiluka, S. O. (2018). Patriarchy and women abuse: Perspectives from ancient Israel and Africa. Old Testament Essays, 31(2), 339-362.

Andok, M. (2019). Gender differences in digital media usage among Hungarian religious community members. ESSACHESS-Journal for Communication Studies, 12(24), 3960.

Andsager, J. L., \& Hust, S. J. (2005). Differential gender orientation in public relations: Implications for career choices. Public Relations Review, 31(1), 85-91.

Barriteau, V. E. (1994). Gender and development planning in the post-colonial Caribbean: Female entrepreneurs and the Barbadian state. (Doctoral dissertation, Howard University).

Beatty, T. U. F. (2013). A historical and analytical study of feminization in the field of public relations. 33. incomplete reference entry. (Thesis, Southeastern University). Retrieved

from https://firescholars.seu.edu/cgi/viewcontent.cgi?article=1023\&context=honors

Daymon, C., \& Demetrious, K. (2010). Gender and public relations: Perspectives, applications and questions. PRism, 7(4), 1-8.

Dodel, M., \& Mesch, G. (2018). Inequality in digital skills and the adoption of online safety behaviors. Information, Communication \& Society, 21(5), 712-728.

Domhoff, G. W. (2012). Class-dominance theory of power. Who Rules America. Retrieved from http://www2.ucsc.edu/whorulesamerica/power/class_domination.html

Douglas, J. (2012). Power, patriarchy and the professions. Retrieved from https://citeseerx.ist.psu.edu/viewdoc/download?doi=10.1.1.495.2980\&rep=rep1\&t ype=pdf

Evans, L. (2002). Reflective practice in educational research. A\&C Black.

Gifford, J. (2010). Digital Public Relations: E-Marketing's Big Secret. Continuing Higher Education Review, 74, 62-72.

Grunig, J. E., \& Dozier, D. M. (2003). Excellent public relations and effective organizations: A study of communication management in three countries. Routledge.

Grunig, L. A., Hon, L. C., \& Toth, E. L. (2013). Women in public relations: How gender influences practice. Routledge.

Grunig, L. A., Toth, E. L., \& Hon, L. C. (2000). Feminist values in public relations. Journal of Public Relations Research, 12(1), 49-68. https://doi.org/10.1207/S1532754XJPRR1201_4

Helsper, E. J., \& Van Deursen, A. J. A. M. (2015). Digital skills in Europe: Research and policy. Digital divides: The new challenges and opportunities of e-inclusion, 195, 125.

Janus, J. M. (2008). Gender, leadership and public relations. (Doctoral dissertation, University of Missouri--Columbia). Retrieved from https://mospace.umsystem.edu/xmlui/bitstream/handle/10355/5768/research.pdf ?sequence=3

Juschka, D. (Ed.). (2001). Feminism in the Study of Religion. A\&C Black.

Kimbrough, A. M., Guadagno, R. E., Muscanell, N. L., \& Dill, J. (2013). Gender differences in mediated communication: Women connect more than do men. Computers in Human Behavior, 29(3), 896-900. 
Krider, D. S., \& Ross, P. G. (1997). The experiences of women in a public relations firm: A phenomenological explication. The Journal of Business Communication (1973), 34(4), 437-453. https://doi.org/10.1177\%2F002194369703400407

Krugler, E. (2017). Women in public relations: The influence of gender on women leaders in public relations. (Graduate Theses and Dissertations, Lowa State University). Retrieved from https://lib.dr.iastate.edu/cgi/viewcontent.cgi?article=6562\&context=etd

Lamme, M. O. (2007). Outside the prickly nest: revisiting doris fleischman. American Journalism, 24(3), 85-107. https://doi.org/10.1080/08821127.2007.10678080

Lester, S. (2015). On professions and being professional. Retrieved December, 14, 2012 from

https://www.researchgate.net/profile/Stan_Lester/publication/282869060_On_pr ofessions_and_being_professional/links/5620d1cf08aed8dd19408501/Onprofessions-and-being-professional.pdf

Little, W., McGivern, R., \& Kerins, N. (2016). Introduction to Sociology-2nd Canadian Edition. BC Campus.

Lovis, K. (2020). Public Relations Activity in Maintaining Image in Financial Technology Industries. Ultimacomm: Jurnal Ilmu Komunikasi, 12(2), 285-300. https://doi.org/https://doi.org/10.31937/ultimacomm.v12i2.1639.

Melgin, E. (2010). Gender imbalance: why is the female-dominated PR industry still led by men? www.ipra.org. Retrieved from https://www.ipra.org/news/itle/genderimbalance-why-is-the-female-dominated-pr-industry-still-led-by-men/

Perrin, A. (2015). Social media usage. Pew research center, 125, 52-68.

Pompper, D., \& Jung, T. (2013). "Outnumbered yet still on top, but for how long?" Theorizing about men working in the feminized field of public relations. Public Relations Review, 39(5), 497-506. https://doi.org/10.1016/j.pubrev.2013.08.007

Reskin, B. F., \& Roos, P. A. (1990). Job queues, gender queues: Explaining women's inroads into male occupations. Temple University Press.

Rolleri, L. A. (2013). Understanding gender and gender equality. Research Facts and Findings.

Retrieved

from

http://www.actforyouth.net/resources/rf/rf_gender1_1213.pdf

Santoso, N. R., \& Negoro, S. H. (2019). Public relations and tourism: finding public relations' role in communicating tourist destination. Jurnal Studi Komunikasi, 3(2), 138-150.

Seitel, F. P. (1995). The practice of public relations. Prentice Hall

Snyder, H. (2019). Literature review as a research methodology: An overview and guidelines. Journal of Business Research, 104, 333-339.

Starr, C. R., \& Zurbriggen, E. L. (2017). Sandra Bem's gender schema theory after 34 years: A review of its reach and impact. Sex Roles, 76(9), 566-578.

Sultana, A. (2010). Patriarchy and Women's Subordination: A Theoretical Analysis. Arts Faculty Journal, 1-18.

Suwana, F. (2017). Empowering Indonesian women through building digital media literacy. Kasetsart Journal of Social Sciences, 38(3), 212-217. 
Tench, R. (2017). One Step Forward, Two Steps Back? An Analysis of European PR Practitioners' Views on the Position of Women in the PR Industry (20092015). Current Politics and Economics of Europe, 28(1).

Thompson, M. J. (2013). A functionalist theory of social domination. Journal of Political Power, 6(2), 179-199.

Toth, E. L., \& Grunig, L. A. (1993). The missing story of women in public relations. Journal of Public Relations Research, 5(3), 153-175.

Tsetsura, K. (2014). Constructing Public Relations as a Women's Profession IN Russia/Construyendo las relaciones públicas como una profesión de mujeres en Rusia. Revista Internacional de Relaciones Públicas, 4(8), 85-110.

Umeogu, B., \& Ifeoma, O. (2012). Gender domination in Nigerian public relations. Advances in Applied Sociology, 2(02), 149.

Zwiech, P. (2009). Discrimination against women in professional life in chosen profeminist theories. Economics and Sociology, 2(1), 96-104. https://doi.org/10.14254/2071-789X.2009/2-1/9 